\title{
Geochemistry of Water and Suspended Particulate in the Lower Yangtze River: Implications for Geographic and Anthropogenic Effects
}

\author{
Xuyin Yuan ${ }^{1 *}$, Jizhou $\mathrm{Li}^{1}$, Changping Mao ${ }^{2}$, Junfeng $\mathrm{Ji}^{2}$, Zhongfang Yang ${ }^{3}$ \\ ${ }^{1}$ College of Environment, Hohai University, Nanjing, China \\ ${ }^{2}$ School of Earth Sciences and Engineering, Nanjing University, Nanjing, China \\ ${ }^{3}$ School of Earth Sciences and Resources, China University of Geosciences, Beijing, China \\ Email: *yxy_hjy@hhu.edu.cn
}

Received October 21, 2011; revised November 9, 2011; accepted December 8, 2011

\begin{abstract}
The lower Yangtze River undergoes intense anthropogenic activities and various natural progress compared to the upper-middle reaches. We explore the aqueous geochemistry of ions and elements of suspended particulate in order to recognize the effects of natural conditions and anthropogenic inputs on rivers. These results show that total dissolved solids of water in the lower Yangtze River are similar as those in the upper-middle reaches of mainstream, but higher in tributaries. The major elements of suspended particulate in high-flow regime (HFR) have approximate concentrations with those in low-flow regime (LFR). But remarkable high concentrations of trace elements in tributaries exhibit regardless of HFR or LFR. Multivariate statistics show the suspended particulate matter (SPM) of mainstream presents similar characteristics in flood season and diverse characteristics in dry season. While SPM of tributaries reveals different results. The majority of suspended matter originates from municipal and industrial discharge both in flood season and dry season, and a part from road runoff in flood season, showing an effect of hydrological regime. Mining activity induces remarkably high concentrations of metals regardless of HFR or LFR. Therefore, the geochemistry of SPM in the lower reach of Yangtze River are significantly affected by the anthropogenic input of different sources, which is different from the upper-middle Yangtze River.
\end{abstract}

Keywords: Suspended Particulate; Major Element; Trace Element; Hydrological Regime; The Yangtze River

\section{Introduction}

The Yangtze River as a lifeline and ecosystem is reported to have degraded drastically during the recent decades. Discharge of industrial wastes, the promoted application of fertilizers, pesticides and herbicides in farming, as well as heavy metal pollution are said to make it one of the most polluted rivers in the world [1,2]. Meanwhile, the local topography, hydrology and geology in the catchment areas determine the wide range of water chemistry conditions observed in streams. Anthropogenic activity may add considerable amounts of pollution compounds, which will influence the existing aquatic system [3]. A careful investigation of sources and geographic distribution of metals has provided evidences for their geogenic origin, and also indicated tributaries be contaminated by human activities [4]. The different hydrological conditions can change the chemical properties of water and particulate, which will also change the speciation of metals [5].

${ }^{*}$ Corresponding author.
The lower reaches of the Yangtze River include the important agricultural and industrial areas, and the economic activities accelerate during recent decades. In its lower part, the Yangtze River drains one of the most populated areas of the world and is also probably affected by the Three Gorges Dam (TGD), which is located in the middle part of this river. Meanwhile, the lower Yangtze River and most of tributaries are close to the river mouth and influenced by the tidal process. It is necessary to investigate geochemistry of water and suspended matter in mainstream and tributaries in the area.

Previous studies have shown the chemical compositions of waters and particulate phases in the Yangtze River, but most sites discussed are located in the uppermiddle river [6-8]. Very few studies focus on chemical compositions in different hydrological regime and the relationships of components between mainstream and tributary. Although the anthropogenic contributions to the chemical composition of the dissolved load of the Yangtze basin rivers have been demonstrated in previous stud- 
ies [7,9], it was not explicitly assessed as an indicator of environmental condition. The interactions of major and trace elements are also absent in these studies, although it is important for aqueous environment.

This paper describes the geochemical characteristics of suspended particulate matter and their changes in different environmental conditions under contrasting river flows in the lower Yangtze River. We also compare the chemical components of waters in lower reaches with those in upper-middle reaches. Another important issue we tackle in this study is the impact of human activities on the particulate metal enrichments of the lower Yangtze basin in different time and space.

\section{Study Area and Background}

The lower Yangtze River is the section from Hukou at Jiangxi-Anhui boundary to river mouth, where the plains and low hills are dominant in the watershed (Figure 1). The lower reaches cover the territory of Anhui Province, Jiangsu Province and Shanghai City, which is one of most dense population and rapidly economic development areas in China. The lower Yangtze watershed is mainly overlain by sedimentary rocks composed of marine carbonates, sandstone, siltstone and magmatic rocks, metamorphic rocks from Precambrian to Quaternary, where sedimentary rocks are the dominant rocks (limestone and sandstone). The gneiss are distributed in the mountainous areas of northern Anhui and granites are distributed in hilly land of southern Anhui. In the southern of Jiangsu, limestone and sandstone are widely spread over the hilly land beside the river. The plain areas expose silty-clay, loam soils and quaternary deposits.

The mainstream of research areas flows through several large cities such as Anqing, Tongling, Wuhu, Nanjing and Nantong, and tributaries flow through different topographies on the basis of position. The river mouth is bifurcated by Chongming Island, and undergoes strong tidal process. The tributaries include Wanhe River, Dasha River, Yuxi River, Jiajiang River, Qingtong River, Shun'an River and Shuiyang River in the study area, and the former four rivers are located in the south of the Yangtze River and the latter three rivers are located in the north side (Figure 1). The bedrocks on upper reaches of Wanhe River are gneiss and granites, Tertiary sandstone and conglomerate on its middle reaches, laterite and brown clay on its lower reaches. The geological setting of Dasha River is similar with Wanhe River, but uplands of metamorphic rock are distributed on its upper-middle reaches, sandstone distributed on its lower reaches with small scale volcanic rocks. The upper reaches of Qingtong River expose acid magmatic rocks, whose chemical compositions are characteristic of near saturated $\mathrm{SiO}_{2}$, with abundant $\mathrm{Fe}$ and $\mathrm{S}$. Its middle and lower reaches are covered by sedimentary rocks such as limestone and sandstone. The upper reaches of Shun'an River are near a $\mathrm{Cu}-\mathrm{Au}$-bearing ore deposit occurring in carbonates of Carboniferous. A great amount of Fe-Mn oxides as ore-bearing gangue are distributed around the mining area. The Shuiyang River flows through an area with acid or neutro-acid magmatic rocks on the upper reaches of southern Anhui, and covers with red sandstone, conglomerate regions on its middle and lower reaches. Wuhu City and Xuanzhou City are located beside the river. The Yuxi River is connected with an eutrophication lake-Chaohu Lake, whose vicinity areas are Hefei City and Chaohu City of Anhui province. The volcanic rocks and phosphorus-bearing carbonates are distributed on its western and northern of the lake, and Mesozoic siltstone, sandstone and Quaternary silty-clay cover the lower reaches [10]. The two sides of Jiajiang River expose the Quaternary loose sediments. The river flows through Yanzhou City and Taizhou City of Jiangsu province and is close to the mouth of Yangtze River.

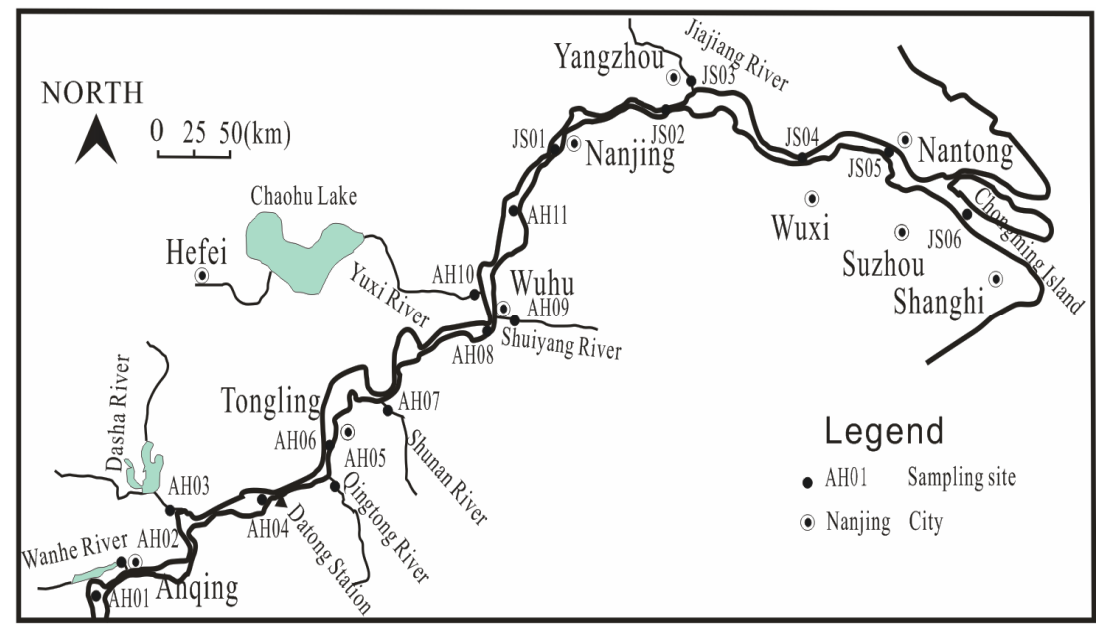

Figure 1. Map showing the research area and sampling sites. 
The water current of the lower Yangtze River is relatively slow in base flow regime as result of flat topography and wide water surface. The average flux of Datong section, Nanjing section and river mouth are $2.90 \times 10^{3}$ $\mathrm{m}^{3} \cdot \mathrm{s}^{-1}, 2.94 \times 10^{3} \mathrm{~m}^{3} / \mathrm{s}$ and $3.2 \times 10^{3} \mathrm{~m}^{3} \cdot \mathrm{s}^{-1}$ respectively. Annual rainfall amount averages $1644 \mathrm{~mm} /$ year for the lower reaches and $1396 \mathrm{~mm} /$ year for the middle reaches, $435 \mathrm{~mm} /$ year for the upper reaches of the Yangtze River [2]. Surface runoff is the major water supply of the Yangtze watershed, accounting for $70 \%-80 \%$ of the total water discharge [7]. Floods in the Yangtze basin are formed by storms which are concentrated between May and October. The temporal and spatial distribution of rainfall in the wet season directly influences amount, transportation and chemical compositions of suspended particulate, which is apparently different from the dry season.

\section{Sampling and Methods}

Samples were collected in July-August 2008 and January 2009, when the Yangtze River encountered high-flow and low-flow period in the research watershed. We collected samples onboard in order to keep a normal hydrologic condition. Ten sampling sites were distributed in mainstream and seven sampling sites in tributaries (Figure 1).

All collection buckets of polythene were cleaned by rinsing with dilute nitric acid, pure water and the sample water. Water was collected manually far from the river bank in a $25 \mathrm{~L}$ acid-cleaned polypropylene. Samples were filtered through pre-weighed $0.45 \mu \mathrm{m}$ cellulose acetate filters (Q/YY8-1-88, Shanghai) in the room within $24 \mathrm{~h}$ after sampling. The vacuum pump was used to take out air from the bottle containing water in order to accelerate the filtration process. Suspended particulate depositing on membrane was collected for analysis.

The membranes were dried before filtrating and weighted in 1/10000 balance for three times until the numerical values were stable. After filtrating, these membranes were dried and weighted in microbalance for three times. The weight of membranes with SPM was reduced by the same vacant membranes weighted before, and the total contents of SPM can be obtained in sampled water. 1L unfiltrated water was collected for aquatic chemical analysis.

Measurements of $\mathrm{pH}$ in the surface water were done with a WTW profilLine 197 H-meter with a SenTix 21 probe. The unfiltrated water was determined for cations and anions in order to discuss aquatic geochemistry of rivers. The major elements $\mathrm{Al}, \mathrm{Fe}, \mathrm{Ca}, \mathrm{Mg}, \mathrm{Na}, \mathrm{K}$ were determined by Inductive Coupled Plasma-Atomic Emission Spectrophotometer (ICP-AES, Er/S, USA). The trace elements $\mathrm{Cr}, \mathrm{Cu}, \mathrm{Zn}, \mathrm{Pb}, \mathrm{Cd}, \mathrm{Co}, \mathrm{Ni}, \mathrm{Se}, \mathrm{Sc}$ and Th were determined by Inductively Coupled Plasma Mass Spectrometry (ICP-MS a Perkin Elmer, Elan 6000, USA) after addition of an indium internal standard solution. Ar- senic (As) and Mercury (Hg) were determined by Atomic Fluorescence Absorption Spectrophotometer (AFS-230E, China).

River particulate from reference material GSS-15 (National Standard Council of China) was digested and analyzed under the same conditions as the sample particulates for both the major and trace elements. Differences between measured and certified values were between $2 \%$ to $6 \%$ for major elements, $4 \%-11 \%$ for trace elements. Also, analytical blanks always gave values less than $5 \%$ of the measured contents.

\section{Results}

\subsection{Compositions of Main Cation and Anion in Water of the Lower Yangtze River}

The ion compositions of water in river originated from rock weathering and anthropogenic input, which can reflect characteristics of local environment. Of cations detected, $\mathrm{Ca}^{2+}$ accounted for the highest proportion $(61.4 \%$ - 63.9\%), following by $\mathrm{Na}^{+}(15.3 \%-20.4 \%), \mathrm{Mg}^{2+}$ $(11.6 \%-14.8 \%), \mathrm{K}^{+}(3.7 \%-6.1 \%)$. Overall, the concentrations of $\mathrm{Ca}^{2+}$ and $\mathrm{Mg}^{2+}$ in mainstream were slightly higher than in tributaries. $\mathrm{HCO}_{3}^{-}$displayed the highest proportion in anions $(56.1 \%-69.0 \%)$, the other anions descended in order of $\mathrm{SO}_{4}^{2-}(17.2 \%-34.0 \%), \mathrm{Cl}^{-}$ $(5.6 \%-8.7 \%)$ and $\mathrm{SiO}_{3}^{2-}(1.5 \%-8.1 \%)$. The minor $\mathrm{F}^{-}$ was less than $0.2 \%$ of total anions. The anions fluctuated more significantly than cations, notably in tributaries. It seemed the total dissolved solids (TDS) were similar between high-flow regime $(223-271 \mathrm{mg} / \mathrm{L})$ and lowflow regime $(233-275 \mathrm{mg} / \mathrm{L})$ in the mainstream of Yangtze River. But they were variable in tributaries (HFR, 104 $363 \mathrm{mg} / \mathrm{L}$, LFR 114 - $500 \mathrm{mg} / \mathrm{L}$ ) (Table 1). Our data of TDS showed higher concentrations than those from Chen et al. (2002) (171.3 mg/L in Datong Station). It is evident that TDS increases with the exploitation along the river in couple of years.

\subsection{Major and Trace Elements of Suspended Particulate in Mainstream}

The major and trace elements of particulate are listed in Table 2. Changes of particulate elemental concentrations were significant between high-flow regime (HFR) and low-flow regime (LFR). The concentrations of major elements ( $\mathrm{Al}, \mathrm{K}, \mathrm{Na}, \mathrm{Mg}$ ) of particulate in mainstream at HFR were similar with those at LFR, but higher Fe and lower $\mathrm{Ca}$ revealed at LFR. The average concentrations of most trace elements were similar at HFR and LFR. But higher $\mathrm{P}, \mathrm{Zn}$ and $\mathrm{Cr}$ presented at LFR, and higher $\mathrm{Cd}$ presented at HFR. The significant differences also presented in samples from different sites, which were associated with mineral components and the geochemical properties of elements [11]. 
Table 1. Ion compositions of natural water in mainstream and tributaries of the lower Yangtze River (mg/L).

\begin{tabular}{|c|c|c|c|c|c|c|c|c|c|c|c|c|}
\hline & \multicolumn{6}{|c|}{ Mainstream } & \multicolumn{6}{|c|}{ Tributary } \\
\hline & \multicolumn{3}{|c|}{ high flow } & \multicolumn{3}{|c|}{ low flow } & \multicolumn{3}{|c|}{ high flow } & \multicolumn{3}{|c|}{ low flow } \\
\hline & Range & Average & $\mathrm{CV}$ & Range & Average & $\mathrm{CV}$ & Range & Average & $\mathrm{CV}$ & Range & Average & $\mathrm{CV}$ \\
\hline $\mathrm{K}^{+}$ & $1.79-9.23$ & 4.24 & 0.73 & $1.63-3.00$ & 2.51 & 0.14 & $2.29-9.65$ & 3.84 & 0.68 & $2.40-5.27$ & 3.46 & 0.37 \\
\hline $\mathrm{Na}^{+}$ & $4.60-18.5$ & 10.8 & 0.44 & $4.56-17.2$ & 13.8 & 0.26 & $5.45-23.1$ & 11.4 & 0.58 & $5.17-25.1$ & 13.6 & 0.62 \\
\hline $\mathrm{Ca}^{2+}$ & $41.9-51.1$ & 45.2 & 0.06 & $40.4-44.8$ & 41.8 & 0.03 & $10.7-76.3$ & 38.5 & 0.53 & $15.5-121$ & 43.8 & 0.82 \\
\hline $\mathrm{Mg}^{2+}$ & $8.15-12.9$ & 10.4 & 0.12 & $7.42-10.1$ & 9.38 & 0.08 & $3.81-12.4$ & 8.92 & 0.31 & $3.93-12.0$ & 8.01 & 0.43 \\
\hline $\mathrm{SO}_{4}^{2-}$ & $20.4-34.6$ & 31.1 & 0.13 & $22.6-43.1$ & 39.5 & 0.16 & $8.90-119$ & 39.4 & 0.91 & $12.5-277$ & 65.4 & 1.13 \\
\hline $\mathrm{Cl}^{-}$ & $5.41-13.51$ & 10.2 & 0.26 & $6.00-20.6$ & 16.6 & 0.25 & $6.76-20.3$ & 11.4 & 0.46 & $7.87-25.1$ & 15.7 & 0.45 \\
\hline $\mathrm{HCO}_{3}^{-}$ & $120-129$ & 125 & 0.02 & $126-143$ & 131 & 0.04 & $51.3-137$ & 108 & 0.26 & $61.5-147$ & 108 & 0.34 \\
\hline $\mathrm{SiO}_{3}^{2-}$ & $11.4-18.3$ & 14.6 & 0.14 & $2.20-5.85$ & 4.05 & 0.27 & $6.61-19.7$ & 12.3 & 0.34 & $1.16-4.11$ & 2.97 & 0.32 \\
\hline $\mathrm{F}^{-}$ & $0.15-0.25$ & 0.21 & 0.16 & $0.14-0.30$ & 0.28 & 0.18 & $0.17-0.38$ & 0.27 & 0.36 & $0.19-0.51$ & 0.31 & 0.44 \\
\hline cations & $56.4-83.0$ & 70.7 & 0.12 & $58.4-72.1$ & 67.4 & 0.06 & $22.4-101$ & 62.7 & 0.41 & $28.7-160$ & 68.9 & 0.65 \\
\hline anions & $167-188$ & 181 & 0.03 & $174-202$ & 192 & 0.04 & $81.2-262$ & 172 & 0.33 & $85.7-340$ & 178 & 0.49 \\
\hline TDS & $223-271$ & 251 & 0.05 & $233-275$ & 259 & 0.05 & $104-363$ & 234 & 0.35 & $114-500$ & 247 & 0.53 \\
\hline $\mathrm{pH}$ & $7.73-8.27$ & 7.97 & 0.02 & $7.59-7.88$ & 7.74 & 0.01 & $7.50-8.24$ & 7.82 & 0.04 & $7.31-7.92$ & 7.60 & 0.04 \\
\hline
\end{tabular}

Table 2. Concentrations of major and trace elements in suspended particulate of mainstream $($ site $=10)$ and tributaries $($ site $=7$ ).

\begin{tabular}{|c|c|c|c|c|c|c|c|c|c|c|c|c|}
\hline \multicolumn{7}{|c|}{ Mainstream } & \multicolumn{6}{|c|}{ Tributary } \\
\hline \multirow{2}{*}{ Items } & \multicolumn{3}{|c|}{ high flow } & \multicolumn{3}{|c|}{ low flow } & \multicolumn{2}{|c|}{ high flow } & \multicolumn{4}{|c|}{ low flow } \\
\hline & Range & Average & $C V$ & Range & Average & $c V$ & Range & Average & $C V$ & Range & Average & $c V$ \\
\hline As (mg/kg) & $21.67-31.54$ & 25.57 & 0.12 & $12.50-43.36$ & 27.89 & 0.37 & $22.28-1438$ & 327.3 & 1.59 & $6.80-61.91$ & 27.46 & 0.74 \\
\hline $\mathrm{Hg}$ & $0.09-1.62$ & 0.38 & 1.35 & $0.08-0.48$ & 0.25 & 0.50 & $0.20-23.14$ & 5.59 & 1.56 & $0.04-0.75$ & 0.42 & 0.67 \\
\hline $\mathrm{Pb}$ & $0.32-238.52$ & 66.69 & 0.96 & $31.42-91.61$ & 68.92 & 0.25 & $58.12-2193$ & 955.8 & 1.08 & $47.68-1584.9$ & 298.60 & 1.90 \\
\hline $\mathrm{Zn}$ & $123.31-237.74$ & 177.8 & 0.17 & $119.5-354.7$ & 251.3 & 0.26 & $71.49-1022$ & 575.28 & 0.64 & 197.5 - 3849 & 1205 & 1.21 \\
\hline $\mathrm{Cu}$ & $5.98-97.50$ & 65.86 & 0.40 & $38.31-125.0$ & 78.29 & 0.28 & $23.24-319.4$ & 187.86 & 0.54 & $51.47-806.8$ & 246.0 & 1.09 \\
\hline $\mathrm{Cd}$ & $0.65-19.98$ & 2.97 & 2.01 & $0.52-2.27$ & 1.52 & 0.35 & $0.11-34.15$ & 6.64 & 1.83 & $0.72-57.88$ & 12.78 & 1.65 \\
\hline $\mathrm{Cr}$ & $87.49-165.9$ & 128.9 & 0.16 & $129.8-376.2$ & 187.80 & 0.37 & $72.53-1388$ & 519.04 & 0.92 & $152.7-316.3$ & 202.1 & 0.28 \\
\hline $\mathrm{Co}$ & $18.53-38.90$ & 23.77 & 0.24 & $14.66-28.16$ & 22.99 & 0.15 & $10.62-68.78$ & 36.15 & 0.57 & $21.37-36.27$ & 28.31 & 0.20 \\
\hline $\mathrm{Ni}$ & $35.61-240.4$ & 70.03 & 0.86 & $34.51-82.71$ & 63.44 & 0.21 & $28.74-271.8$ & 135.12 & 0.72 & $56.98-256.7$ & 98.79 & 0.72 \\
\hline $\mathrm{Sc}$ & $11.88-51.28$ & 19.3 & 0.60 & $9.87-19.60$ & 17.14 & 0.16 & $10.38-91.49$ & 41.94 & 0.69 & $8.31-28.36$ & 19.09 & 0.35 \\
\hline Th & $6.57-17.69$ & 14.01 & 0.22 & $11.60-22.44$ & 19.99 & 0.17 & $9.17-67.69$ & 35.62 & 0.69 & $8.88-33.38$ & 20.68 & 0.35 \\
\hline $\mathrm{P}$ & $14.57-1063$ & 800.8 & 0.37 & $611.02-3111$ & 1551 & 0.47 & $499.7-16959$ & 7680 & 0.90 & $1433-14436$ & 3946 & 1.18 \\
\hline $\mathrm{Al}(\%)$ & $8.36-9.83$ & 9.16 & 0.05 & $8.16-10.66$ & 9.68 & 0.07 & $9.23-11.85$ & 10.48 & 0.09 & $9.93-12.36$ & 11.21 & 0.07 \\
\hline $\mathrm{Fe}$ & $3.43-5.76$ & 4.71 & 0.15 & $3.10-7.08$ & 5.52 & 0.19 & $4.49-8.14$ & 6.09 & 0.24 & $5.91-9.79$ & 7.55 & 0.17 \\
\hline K & $1.55-2.61$ & 2.22 & 0.15 & $1.55-2.81$ & 2.41 & 0.14 & $1.46-3.04$ & 2.18 & 0.26 & $1.55-3.81$ & 2.44 & 0.30 \\
\hline $\mathrm{Na}$ & $0.37-0.62$ & 0.51 & 0.15 & $0.37-0.66$ & 0.50 & 0.20 & $0.56-1.98$ & 0.99 & 0.47 & $0.32-2.03$ & 0.86 & 0.67 \\
\hline $\mathrm{Mg}$ & $1.43-1.87$ & 1.64 & 0.10 & $1.33-1.95$ & 1.60 & 0.13 & $1.54-3.01$ & 2.11 & 0.25 & $1.16-3.00$ & 1.81 & 0.36 \\
\hline
\end{tabular}

Unit in $\mathrm{mg} / \mathrm{kg}$ for trace elements, \% for $\mathrm{Al}, \mathrm{Fe}, \mathrm{K}, \mathrm{Na}, \mathrm{Ca}, \mathrm{Mg}$. 


\subsection{Major and Trace Elements of Suspended Particulate in Tributary}

The major elements of suspended matter in tributaries were slightly higher than in mainstream, especially at LFR. Calcium showed remarkable high concentrations in sites AH07 and AH10, which revealed the effect of urban material [12]. The concentrations of trace elements in tributaries fluctuate in a large scale, along with the ambient circumstance. These elements in tributaries were evidently elevated compared to those in mainstream. Contrasting with the mainstream, trace elements of particulate in tributaries are higher at LFR than at HFR, especially for the anthropogenic elements $\mathrm{Cu}, \mathrm{Pb}, \mathrm{Zn}, \mathrm{Cd}, \mathrm{Ni}$.

Both major and trace elements were distinctive in different tributaries. Particulate $\mathrm{Al}$ and $\mathrm{Fe}$ were higher in Wanhe River and Dasha River, which drained the metamorphic rock layer of mountainous areas in the upstream. The high concentrations of metals appeared in the vicinity of cities. Metal concentrations in Shun'an River showed elevated values, notably for $\mathrm{Cu}, \mathrm{Pb}, \mathrm{Zn}, \mathrm{Cd}$ and $\mathrm{As}$. In the high-flow period, the average metal concentrations of particulate were the least in Jiajiang River. In the lowflow period, Wanhe River showed the least average values of particulate metals. Mercury, $\mathrm{Pb}, \mathrm{Zn}, \mathrm{Cd}$ and $\mathrm{As}$ in Dasha River and Shuiyang River at HFR were elevated, and $\mathrm{Hg}$ and $\mathrm{Pb}$ were $1-2$ grade higher than those in other rivers. The highest $\mathrm{Cd}$ existed in Shun'an River, and highest $\mathrm{Cr}$ in Wanhe River. At LFR, particulates in Shun'an River are enriched in $\mathrm{Cu}, \mathrm{Pb}, \mathrm{Zn}, \mathrm{Cd}$ and As. Cadmium of particulates in Shun'an River and Qingtong River was one grade higher than in other rivers. Particulate phosphorus at HFR was much higher than at LFR, notably for Wanhe River and Yuxi River. Some elements easily influenced by the weathering material such as Sc, Th and Co also fluctuate obviously in two hydrologic conditions, which suggest the natural input also make important effects on the aqueous chemical compositions.

\section{Discussion}

\subsection{Aqueous Geochemistry of the Lower Yangtze River}

Chemical components of riverine water consist of dissolved and particulate matter, which originate from the surrounding weathering rocks, soils and anthropogenic input. Compared to the upper-middle Yangtze River, the lower Yangtze River suffers from more intense human activities and tidal process. The ranges of TDS in high-flow condition were 223 to $271 \mathrm{mg} / \mathrm{L}$, average $251 \mathrm{mg} / \mathrm{L}$. The concentrations of TDS in low-flow condition were 233 to $275 \mathrm{mg} / \mathrm{L}$, average $259 \mathrm{mg} / \mathrm{L}$, which was slightly higher than the average value $206 \mathrm{mg} / \mathrm{L}$ (ranging from 49.7 to $518.1 \mathrm{mg} / \mathrm{L}$ ) of whole Yangtze River [7]. TDS in the mainstream were similar at HFR and LFR. But they showed more fluctuations in tributaries (104 - $363 \mathrm{mg} / \mathrm{L}$ at HFR,
$114-600 \mathrm{mg} / \mathrm{L}$ at LFR). It is concluded that the chemical components of main channel in the lower Yangtze River are relatively stable and evidently affected by regional geological setting, but the aquatic chemical components of tributaries are markedly affected by anthropogenic sources.

The median TDS concentration in Yangtze River is similar to that of the Ganges- Brahmaputra in Asia and the Mackenzie in North America, but is more than three times the global median of $65 \mathrm{mg} / 1$ [13]. For most rivers in the world, the enhanced dissolution of detrital calcite is likely since suspended solid concentration in the flood season can reach 6 - 55 times that in the dry season [14,15], but there are no such large discrepancies in the lower Yangtze River between HFR and LFR. That is correlated with plain terrain with mature soils in the research watershed.

The lowest values of TDS were observed in rivers draining mainly granitic and volcanic rocks in small basins (Wanhe River). The highest values were observed in rivers draining mainly sedimentary formations with metal mines (Shun'an River).For rivers in the world, those waters draining silicate-rich bedrock were dominantly Na$\mathrm{Cl}$ in composition and had low total dissolved solids (TDS $0.1-0.4 \mathrm{~g} / \mathrm{L}$ ). Those waters draining sedimentaryrich bedrock were dominantly $\mathrm{Na}-\mathrm{Ca}-\mathrm{Cl}-\mathrm{HCO}_{3}^{-}$in composition and had higher TDS $(0.6-1.2 \mathrm{~g} / \mathrm{L})$ [16]. The waters in the lower Yangtze River are of character for these ions, but are lower concentrations of TDS.

$\mathrm{Ca}^{2+}$ was the main cation in the lower Yangtze River, $\mathrm{K}^{+}$and $\mathrm{Na}^{+}$varied significantly, but $\mathrm{Mg}^{2+}$ was relatively less fluctuated. Compared with the upper-middle Yangtze River, the lower reaches showed lower $\mathrm{Mg}^{2+}$ and higher $\mathrm{K}^{+}+\mathrm{Na}^{+}$. In contrast to cations, anions didn't show significant fluctuation, except a few samples. The concentrations of $\mathrm{HCO}_{3}^{-}$and $\mathrm{H}_{2} \mathrm{SiO}_{3}$ were lower, $\mathrm{SO}_{4}^{2-}$ and $\mathrm{Cl}^{-}$were higher here compared to the upper-middle Yangtze River [7]. The aqueous geochemistry of tributaries is influenced evidently by anthropogenic input in the study area (Figures 2 and $\mathbf{3}$ ).

For the mainstream, the ion plots showed remarkable diversities in Figure 2. $\mathrm{Na}^{+}$and $\mathrm{Cl}^{-}$fluctuated sharply and $\mathrm{SO}_{4}^{2-}$ and $\mathrm{HCO}_{3}^{-}$changed moderately. $\mathrm{Ca}^{2+}$ and $\mathrm{Mg}^{2+}$ maintained relatively steady contents. The ion concentrations of water at HFR were lower than at LFR. $\mathrm{Mg}^{2+}, \mathrm{HCO}_{3}^{-}$and $\mathrm{SO}_{4}^{2-}$ increased slightly at LFR. This is associated with decreasing suspended particulate, which reduces the adsorption on ions [17]. $\mathrm{Na}^{+}$and $\mathrm{Cl}^{-}$ increase substantially as a result of the intrusion of brackish water.

The tributaries are located in the different small watersheds and receive multi-source matter. So the plots dispersed in the figures, which were related with geological setting, tidal process and anthropogenic activities (Figure 3). Samples of Wanhe River were situated in the upstream of Datong hydrologic station (the farthest site tide 

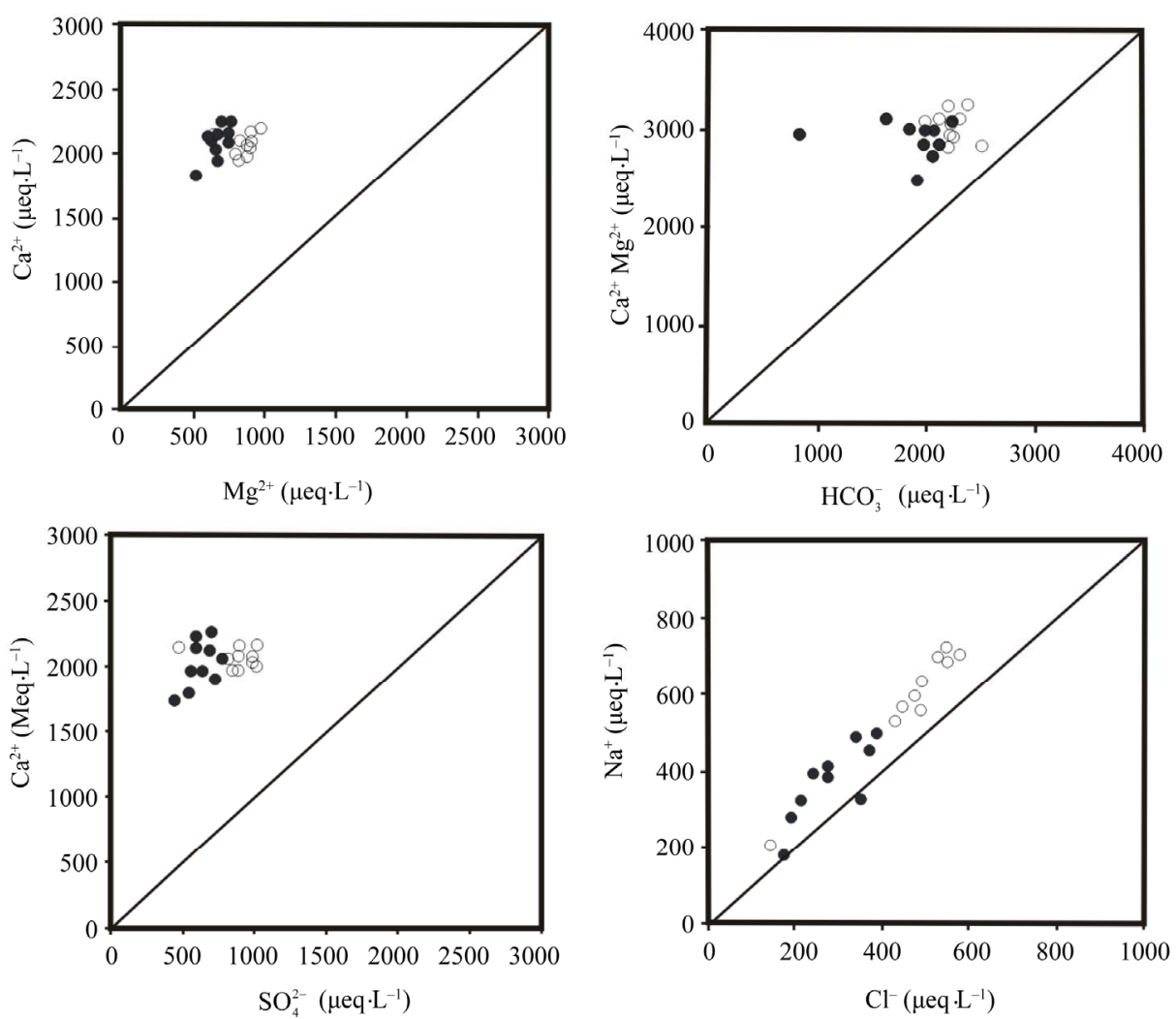

Figure 2. Diagram of cations and anions for mainstream at HFR and LFR in the lower Yangtze River. High-flow regime is displayed by closed circle, Low-flow regime is displayed by open circle.
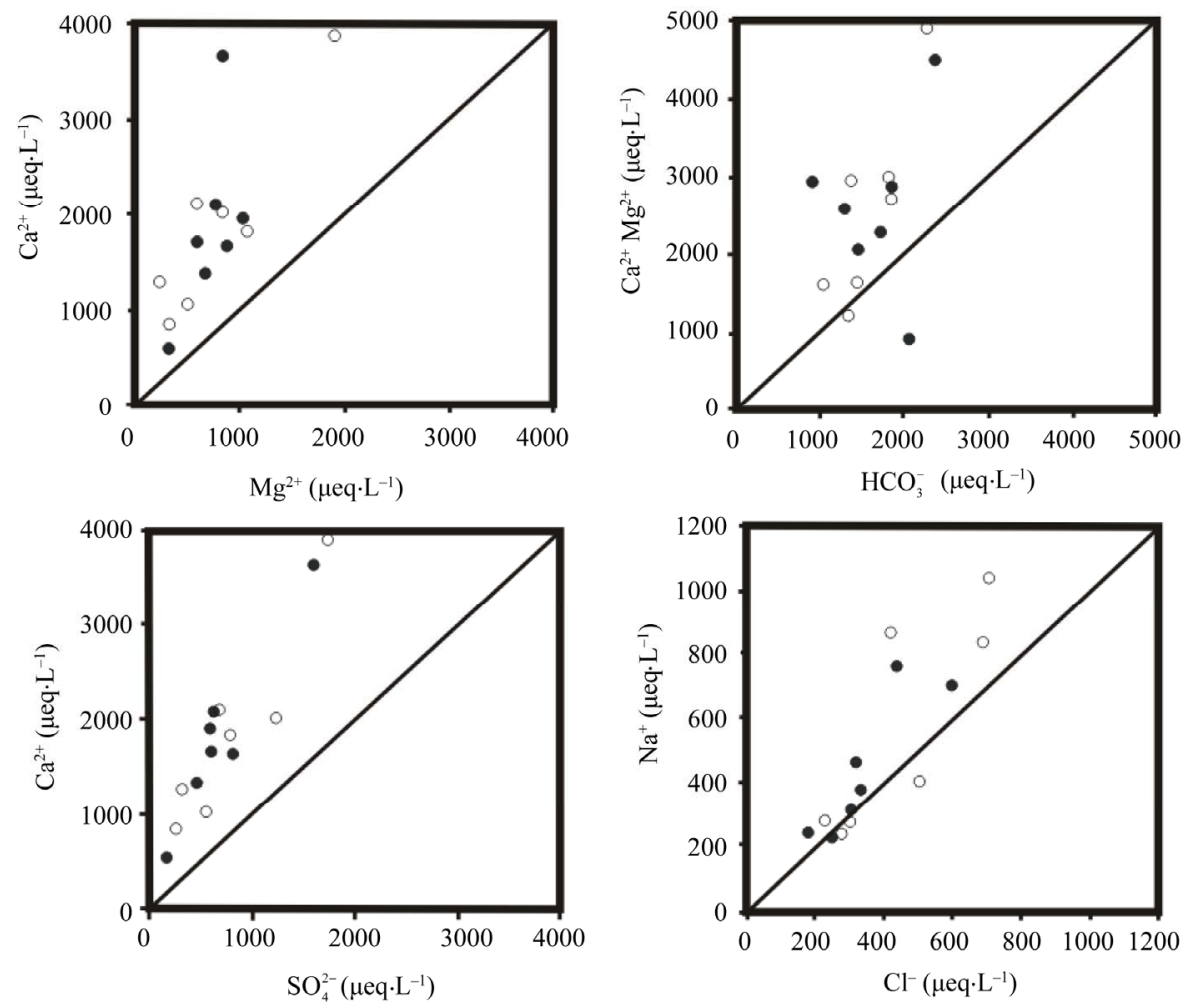

Figure 3. Diagram of cations and anions for tributaries at HFR and LFR in the lower Yangtze River. Closed circle represents high-flow regime; Open circle represents low-flow regime. 
can reach), which had elevated $\mathrm{Ca}^{2+}, \mathrm{Mg}^{2+}$ and low $\mathrm{Cl}^{-}$, $\mathrm{Na}^{+}$. The concentration of $\mathrm{Mg}^{2+}, \mathrm{Ca}^{2+}, \mathrm{SO}_{4}^{2-}$ and $\mathrm{HCO}_{3}^{-}$in Shun'an River were significantly higher than in other tributaries. Because the upstream of the river was located in a mining area and the parent rocks with ores were carbonates. The Jiajiang River had evident high $\mathrm{Na}^{+}$and $\mathrm{Cl}^{-}$, due to the close site to the river mouth.

The plots of samples in tributaries were scattered in Figure 3, which were associated with geographical and external input. The high concentration sample of $\mathrm{Ca}^{2+}$, $\mathrm{Mg}^{2+}$ and $\mathrm{SO}_{4}^{2-}$ were collected in a river impacted by mining activity (Shun'an River, AH07), which showed slight influence for different hydrological regimes. The samples of high $\mathrm{Na}^{+}$and $\mathrm{Cl}^{-}$concentrations were located near by the city (AH03), or close to the river mouth $(\mathrm{AH}$ 10, JS03). Moreover, these sites revealed variable ion contents at HFR and LFR.

\subsection{Distribution and Accumulation of Trace Elements in Suspended Particulate}

As motioned above, the concentrations fluctuated obviously for most elements in different hydrological regimes. The concentrations of particulate trace elements were a little higher at LFR than at HFR for most samples of mainstream. And $\mathrm{Cd}$ and $\mathrm{Pb}$ displayed remarkable changes at HFR, $\mathrm{P}$ and $\mathrm{Cr}$ were shifty elements at LFR.

The concentrations of trace elements in tributaries prominently changed. Those elements influenced slightly by human activities (Sc, Th, Se, Co) also revealed obvious fluctuations in different sites, which were influenced by local rocks and soils. The changes in the concentrations of $\mathrm{Cu}, \mathrm{Pb}, \mathrm{Zn}, \mathrm{Cr}, \mathrm{As}$ and $\mathrm{P}$ observed at HFR and LFR may be due to adsorption onto a variety of metal-bearing (especially Al, Fe and Mn) oxide and hydroxide minerals [18].

The enrichment ratio can reflect the accumulation degree of trace elements in rivers. Based on the background value of trace elements $(\mathrm{Cu}, \mathrm{Pb}, \mathrm{Zn}, \mathrm{Cr}, \mathrm{Cd}, \mathrm{As}, \mathrm{Ni}, \mathrm{P})$ in sediment of the lower Yangtze River [19], we calculate the enrichment factor (EF) of each element in suspended particulate. Then we plus all EFs of eight elements to get total enrichment factor (TEF). The formula is expressed as follows.

$$
\mathrm{EF}_{i}=M_{i} / M_{b}, \mathrm{TEF}=\Sigma \mathrm{EF}_{i}
$$

where $M_{i}$ is the concentration detected for one metal, and $M_{b}$ is the background value of the metal in the lower Yangtze River. TEF is total value of eight enrichment factors.

The enrichment factors of eight trace elements were showed in Figure 4. These factors of trace elements for most sites were higher at LFR than at HFR, especially for phosphorus. It was indicated most elevated elements from anthropogenic activities had been mixed and diluted by matter from geological clastics. But the enrichment factors of $\mathrm{Cd}, \mathrm{Ni}$ and $\mathrm{Pb}$ at individual sites (AH11 and JS01) were evidently larger at HLR than at LFR. They were apparently related with the industrial discharge from surrounding cities.

Obvious diversities of elemental enrichment appeared in tributaries. Contrary to elements in mainstream, the enrichment factors of most elements were higher at HFR in tributaries, especially for $\mathrm{As}, \mathrm{Pb}$ and $\mathrm{Cr}$. The enrichment factors of trace elements in Shun'an River at LFR were higher than at HFR, as a result of influence by mining discharge. The elevated trace elements at HFR were deduced from runoff of surrounding cities [20].

Figure 5 showed the distribution of TEFs in suspended particulate of different sites. Two curves in the same diagram represented samples collected at HFR and LFR. TEFs of most samples were affected by the hydrological regime. Samples at LFR showed higher TEFs in most mainstream sites. But a few samples in same sites showed a little difference at HFR and LFR like Site AH06 and AH08. The two sites were distributed in rural area and far away from the tributary, which indicated the external input was significant for metal enrichment. Site AH11 showed much enriched for trace elements at HFR due to inputs of two tributaries in flood season. The changes of JS06 revealed a higher enrichment at HFR, showing influence of urban runoff from Suzhou and Shanghai. Otherwise, the river mouth undergoes an intense mixture between fresh water and salty water. The relatively low concentrations of trace elements originated from dilution of sea water [21].

For tributaries, the significant diversities existed at HFR and LFR. Site AH02 and AH03 showed (Wanhe River and Dasha River) high enrichment factors of $\mathrm{Pb}$, As and $\mathrm{Cr}$ at HFR, which were associated with basic metamorphic rocks in this watershed. This is a hilly area where soils will be eroded easily. Site AH07 (Shun'an River) displayed high enrichment factors of $\mathrm{Cd}, \mathrm{Pb}, \mathrm{Zn}$ and $\mathrm{Cu}$ at LFR, indicating the influence of mining. Yuxi River (AH10) was enriched in $\mathrm{P}, \mathrm{Pb}, \mathrm{Zn}$ and $\mathrm{Cr}$ at HFR, which received great amount of domestic discharge from Lake Caohu (upstream). The low TEFs appeared at Jiajiang River and Shuiyang River (AH09 and JS03) of plain area and rural area, which have received less eroded material from lands and direct pollutant discharge.

\subsection{Multivariate Statistics of Chemical Compositions in Mainstream and Tributaries}

\subsubsection{Cluster Analysis}

We can recognize the characteristics of sample and element assembly by cluster analysis (CA) of chemical compositions. Q-type cluster analysis of twenty three components was performed and results were showed in Figure 6. Most samples were classified as a similar group in Figure 6(a), which suggested chemical compositions of particulate were relatively stable in mainstream in flood season. 

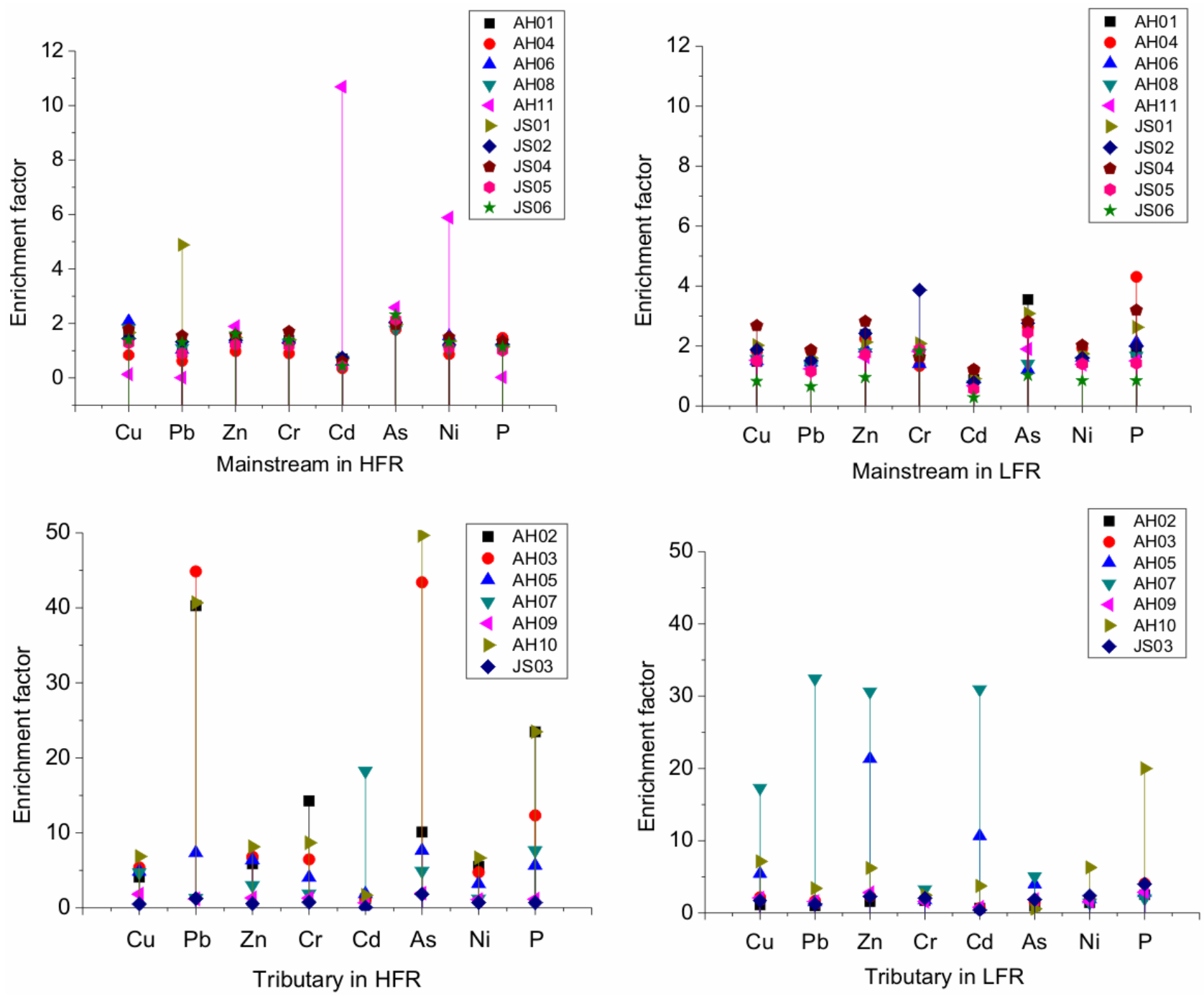

Figure 4. Diagrams showing enrichment factors of trace elements in different sites.
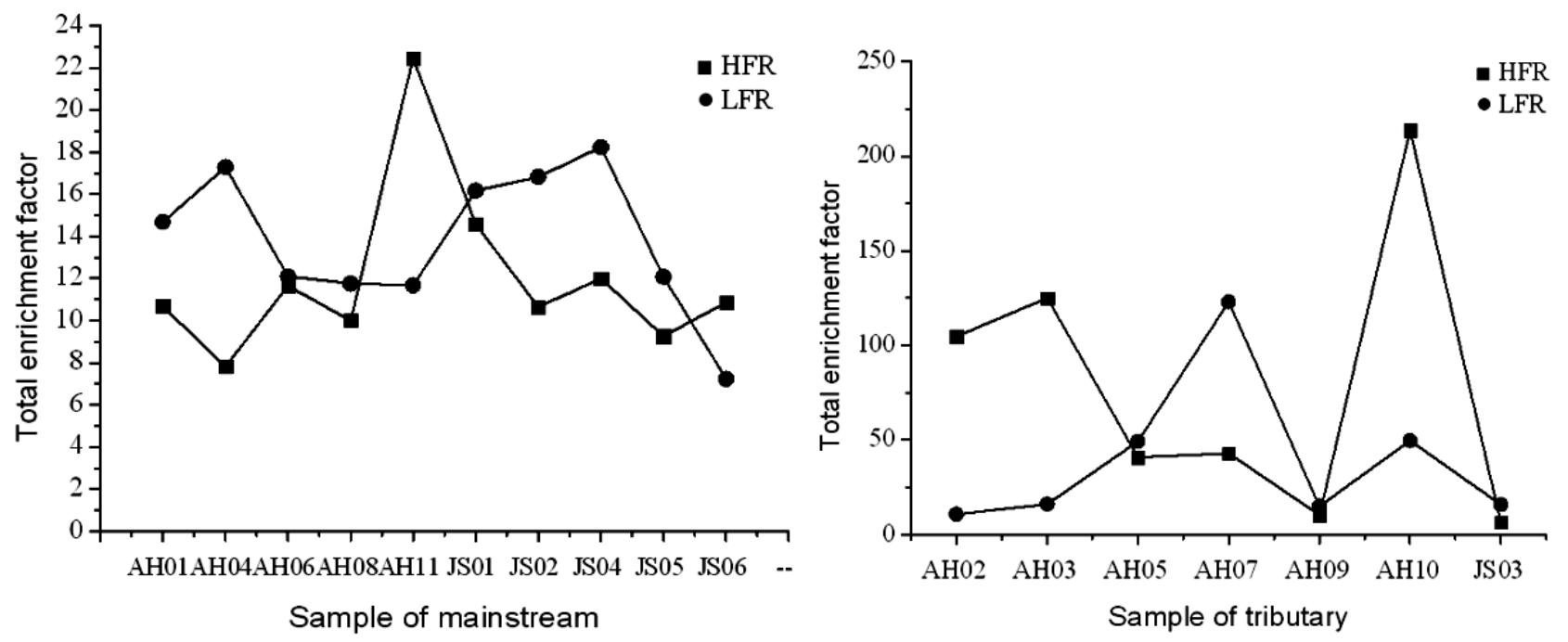

Figure 5. Total enrichment factors of seven trace elements for mainstream and tributary. 


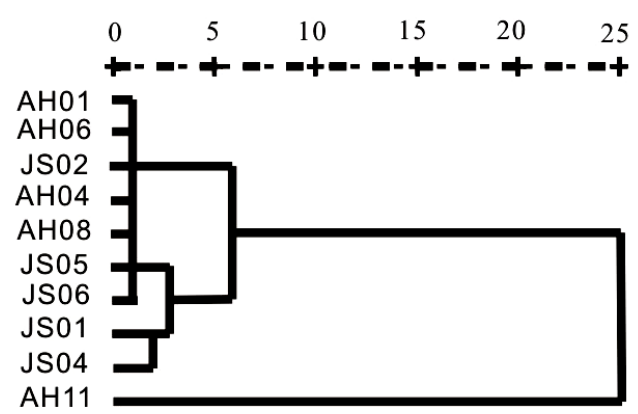

(a)

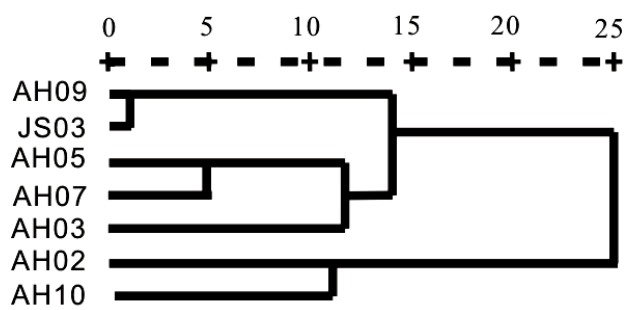

(c)

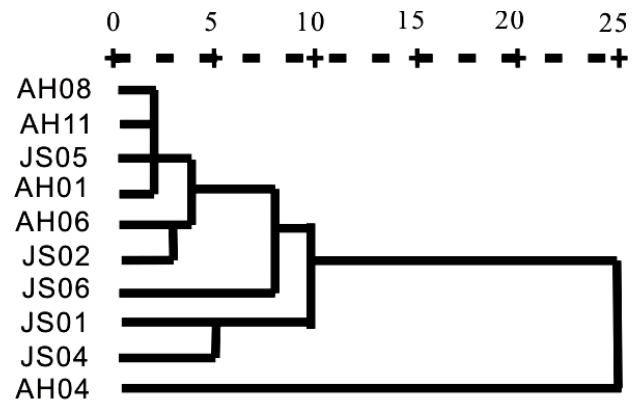

(b)

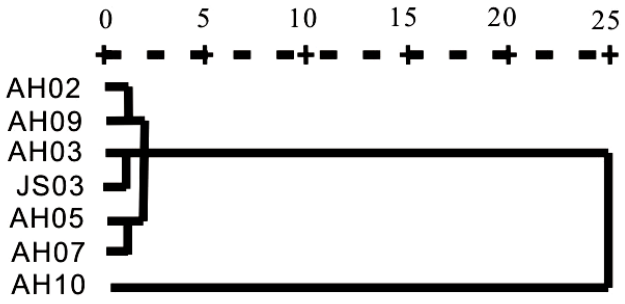

(d)

Figure 6. Q-type cluster analysis of samples from mainstream and tributary. (a) Samples of mainstream at HFR; (b) Samples of mainstream at LFR; (c) Samples of tributary at HFR; (d) Samples of tributary at LFR.

The site AH11 was affected by tributary input of Yuxi River and Shuiyang River, which was different from other samples. But sample sites can be divided into three groups at dry season based on the correlation distance. The site AH04 was influenced by Wanhe River and Dasha River. Sample sites of tributaries showed an inverse trend compared to mainstream. Samples of tributaries at flood season showed several groups with the correlation distance, which were associated with local geological and anthropogenic sources. Most samples of dry season were classified as a group expect AH10, showing less input from watershed. Sample AH10 showed high P, Al, Fe and Mn, indicating suspended matter from Lake Caohu [22].

\subsubsection{Primary Component Analysis of Elements in Two Seasons}

Primary component analyses of 23 elements of samples were manipulated for HFR and LFR.

Factor scores by rotating were showed in Table 3. Based on the eigenvalue of exceeding 1 , four factors were acquired at HFR. The eigenvalues of factor were 13.2, 2.3, 2.0 and 1.0, which accounted for $62.9 \%, 10.8 \%$, $9.7 \%$ and $4.9 \%$ variance for first to fourth factor respecttively.

According to elemental group of factor score, the first factor was explained as matter from the municipal and industrial sources (including mining). The second factor showed a geological source. The third factor reflected matter from road runoff [23], and the fourth factor represented source of upstream. It is evidently the municipal and industrial sources are dominant.
Three factors were acquired at LFR. The eigenvalues of factor were 8.7, 7.4 and 1.8, which accounted for $41.6 \%$, $35.2 \%$ and $8.6 \%$ variance for first to third factor respecttively. The elemental groups were explained as industrial, municipal and geological sources in order. The variance percentages were similar for first factor and second factor, reflecting both as dominant sources at LFR.

Particulate sources showed differences at HFR and LFR. Frequent rainfall induced mixing of the municipal and industrial discharge, which occupied majority of external particulate in flood season. And particulate from upstream also appeared in the research area. But the dry season lack a great amount of flow, material from municipal and industrial discharge can be discriminated. Less road deposit was washed out as a result of rarely raining in dry season.

\subsection{The Effects of Geological and Anthropogenic Characteristics on Geochemical Components in the Lower Yangtze River}

The present researches suggest that the $\mathrm{pH}$ makes a significant effect on the distributions of metals in suspended solid [24]. In our research, the $\mathrm{pH}$ values were 7.73 8.24 at HFR, $7.59-7.88$ at LFR for mainstream of the lower Yangtze River, $7.50-8.24$ at HFR, $7.31-7.92$ at LFR for tributaries. It is obvious that $\mathrm{pH}$ of water at LFR is lower than that at HFR in this watershed, and $\mathrm{pH}$ of tributary water is lower than that of mainstream. The lower $\mathrm{pH}$ of water may result from anthropogenic matter such as industrial discharge [25]. 
Table 3. Primary component analysis of elements and factor scores for suspended particulate matter in two seasons.

\begin{tabular}{|c|c|c|c|c|c|c|c|c|c|}
\hline \multirow[t]{2}{*}{ Elements } & \multicolumn{5}{|c|}{ Samples in flood season } & \multicolumn{4}{|c|}{ Samples in dry season } \\
\hline & Factor 1 & Factor 2 & Factor 3 & Factor 4 & Community & Factor 1 & Factor 2 & Factor 3 & Community \\
\hline As & & 0.704 & & & 0.916 & & & 0.544 & 0.704 \\
\hline $\mathrm{Hg}$ & & 0.659 & & & 0.860 & & & 0.862 & 0.796 \\
\hline $\mathrm{Se}$ & & 0.722 & & & 0.920 & & & 0.747 & 0.790 \\
\hline Mo & & & & 0.915 & 0.924 & & 0.960 & & 0.943 \\
\hline $\mathrm{Na}$ & & 0.661 & & & 0.898 & 0.869 & & & 0.894 \\
\hline $\mathrm{Mg}$ & & 0.841 & & & 0.806 & 0.895 & & & 0.814 \\
\hline $\mathrm{K}$ & & 0.849 & & & 0.886 & 0.874 & & & 0.836 \\
\hline $\mathrm{Ca}$ & & & 0.770 & & 0.828 & & 0.935 & & 0.960 \\
\hline $\mathrm{Al}$ & 0.817 & & & & 0.868 & 0.714 & & & 0.854 \\
\hline $\mathrm{Fe}$ & 0.918 & & & & 0.917 & 0.745 & & & 0.931 \\
\hline $\mathrm{Mn}$ & & & 0.665 & & 0.828 & 0.569 & & & 0.720 \\
\hline $\mathrm{Ni}$ & 0.911 & & & & 0.852 & 0.957 & & & 0.957 \\
\hline $\mathrm{P}$ & 0.867 & & & & 0.867 & 0.948 & & & 0.961 \\
\hline $\mathrm{Zn}$ & 0.893 & & & & 0.960 & & 0.819 & & 0.854 \\
\hline $\mathrm{Sc}$ & 0.916 & & & & 0.944 & 0.863 & & & 0.957 \\
\hline $\mathrm{Cr}$ & 0.907 & & & & 0.836 & & 0.577 & & 0.337 \\
\hline Co & 0.930 & & & & 0.965 & & 0.679 & & 0.909 \\
\hline $\mathrm{Cu}$ & 0.728 & & & & 0.907 & & 0.954 & & 0.985 \\
\hline $\mathrm{Cd}$ & & & 0.887 & & 0.838 & & 0.909 & & 0.972 \\
\hline $\mathrm{Pb}$ & 0.866 & & & & 0.907 & & 0.916 & & 0.943 \\
\hline Th & 0.853 & & & & 0.802 & 0.823 & & & 0.805 \\
\hline
\end{tabular}

$\mathrm{Ca}^{2+}$ of water is higher and $\mathrm{Mg}^{2+}$ is similar in mainstream, $\mathrm{K}^{+}$and $\mathrm{Na}^{+}$are higher in the river mouth compared to the data from Chen et al. (2002). Most anions such as $\mathrm{HCO}_{3}^{-}$in the lower reaches are less than those in the upper-middle reaches. But $\mathrm{SO}_{4}^{2-}$ increases in the lower reaches, which originates from anthropogenic input [26]. $\mathrm{Cl}^{-}$is elevated in the upper Yangtze River (influenced by evaporation rocks), decreases in the middle reaches and lowest at Datong station in the lower reaches [7]. But it increases toward the river mouth, showing the effect of blackish water. $\mathrm{H}_{2} \mathrm{SiO}_{3}$ is extraordinary in the lower reaches, which is $3-5$ times at HFR than at LFR, even if in tributaries. It is deduced that the material with high $\mathrm{H}_{2} \mathrm{SiO}_{3}$ input by the runoff at HFR.

The rivers flowing through volcanic and metamorphic rocks areas (Wanhe River and Dasha River) show a low concentration of $\mathrm{Ca}^{2+}$. If rivers flow through carbonate rocks areas (Qingtong River and Yuxi River), $\mathrm{Ca}^{2+}$ increases significantly. The changing trend of $\mathrm{HCO}_{3}^{-}$is similar with that of $\mathrm{Ca}^{2+} . \mathrm{H}_{2} \mathrm{SiO}_{3}$ shows significant changes in tributaries, which is consistent with the distribution of background rocks. $\mathrm{SO}_{4}^{2-}$ is a relative steady component (except Shun'an River) although it increases slightly with anthropogenic input in the study area. Most of cations show slight fluctuations in rivers, but $\mathrm{Na}^{+}$and
$\mathrm{Ca}^{2+}$ reveal different concentrations in tributaries. In Shun'an River, $\mathrm{Ca}^{2+}$ is $2-3$ fold larger than other rivers, because its upper stream receives the discharge from a mining region with carbonate bedrock. The high concentrations of $\mathrm{Cl}^{-}$in tributaries should originate from anthropogenic input, other than brackish water. $\mathrm{Cl} / \mathrm{Na}$ in most samples are more than 1 , which shows a obviously effect by agricultural and industrial dust [26,27], especially remarkably at LFR.

As mentioned above, the anthropogenic inputs take a relatively weak effect on major elements and trace elements of suspended particulate in mainstream, but a strong effect on those in tributaries. The concentrations of $\mathrm{Pb}$ are significantly elevated at HFR. It is deduced that particulate $\mathrm{Pb}$ from road dusts enters rivers with runoff in flood season, which is associated with rainstorm. Suspended particulate shows high concentrations of $\mathrm{Cu}, \mathrm{Zn}$ and $\mathrm{Cd}$ in Shun'an River, which flows through a mining area. Phosphorus is correlated with the discharge of domestic sewage, which reveals high concentrations of particulate phase at HFR, and low concentrations at LFR, especially for samples in Dasha River, Wahe River and Yuxi River. As a rule, the concentration of $\mathrm{Hg}$ is essential constant in most studied rivers, but it increases rapidly in some sites nearby big cities (such as Nanjing and 
Wuhu). It is contributed by industrial discharge. Therefore, trace elements in the tributaries are significantly affected by anthropogenic inputs.

\section{Conclusions}

According to the chemical components of water and suspended particulate, the remarkable differences present in suspended particulate and the slight differences display in water of the lower Yangtze River. The concentrations of dissolved solids are mainly affected by the geographical location. The aqueous chemistry of mainstream shows a major geological origin, following by the tidal process and input of tributaries. It is evident that TDS increases in the research watershed compared to data several years ago, which is related in industrial and municipal discharge.

The major elements and trace elements are enriched in suspended particulate of tributaries in usual circumstances. And polluted elements in tributaries are obviously several times higher than those in mainstream, indicating more contaminants from human activities. Trace elements in mainstream show small fluctuation of suspended particulate in flood season, due to dilution of large water yield on external matter. But the concentrations of trace elements are elevated in dry season. The accumulation of trace elements is mainly influenced by the hydrological condition in mainstream, but by anthropogenic input in tributary. Primary components analysis of elements at HFR and LFR shows the industrial and municipal discharge is the origin of elemental enrichment for suspended particulate in the lower Yangtze River.

As a whole, the geochemical components in the lower Yangtze River are affected by the anthropogenic input, geographical location and tide process, which is different from the upper-middle Yangtze River.

\section{Acknowledgements}

The authors will deliver their appreciation to Dr. Yinxian Song, Tong He and Bing Li for their help in sample collecting. This work is supported by the public welfare fund of Ministry of Land and Resources of China (12108 20109, 201111021).

\section{REFERENCES}

[1] Y. Wu, J. Zhang and Q. Zhou, "Persistent Organochlorine Residues in Sediments from Chinese River/Estuary Systems," Environmental Pollution, Vol. 105, No. 1, 1999, pp. 143-150. doi:10.1016/S0269-7491(98)00160-2

[2] Z. Chen, J. Li, H. Shen and Z. Wang, "Yangtze River of China: Historical Analysis of Discharge Variability and Sediment Flux," Geomorphology, Vol. 41, No. 2-3, 2001, pp. 77-91.

[3] P. Gundersen and E. Steinnes, "Influence of $\mathrm{pH}$ and TOC
Concentration on $\mathrm{Cu}, \mathrm{Zn}, \mathrm{Cd}$ and $\mathrm{Al}$ Speciation in Rivers," Water Research, Vol. 37, No. 2, 2003, pp. 307-318. doi:10.1016/S0043-1354(02)00284-1

[4] Q. Z. Yao, J. Zhang, Y. Wu and H. Xiong, "Hydrochemical Processes Controlling Arsenic and Selenium in the Changjiang River (Yangtze River) System," Science of The Total Environment, Vol. 377, No. 1, 2007, pp. 93-104. doi:10.1016/j.scitotenv.2007.01.088

[5] L. Björkvald, I. Buffam, H. Laudon and C. M. Mörth, "Hydrogeochemistry of $\mathrm{Fe}$ and $\mathrm{Mn}$ in Small Boreal Streams: the Role of Seasonality, Landscape Type and Scale," Geochimica et Cosmochimica Acta, Vol. 72, No. 12, 2008, pp. 2789-2804. doi:10.1016/j.gca.2008.03.024

[6] L. C. Zhang, S. Zhang, W. J. Dong and L. J. Wang, "Geochemistry of Aquatic Environment in the Headstream of the Yangtze River," Press of Environmental Sciences of China, Beijing, 1992.

[7] J. Chen, F. Wang, X. Xia and L. Zhang, "Major Element Chemistry of the Yangtze (Yangtze River)," Chemical Geology, Vol. 187, No. 3-4, 2002, pp. 231-255. doi:10.1016/S0009-2541(02)00032-3

[8] B. Chetelat, C. Q. Liu, Z. Q. Zhao, Q. L. Wang, S. L. Li, J. Li and B. L. Wang, "Geochemistry of the Dissolved Load of the Yangtze Basin Rivers: Anthropogenic Impacts and Chemical Weathering," Geochimica et Cosmochimica Acta, Vol. 72, No. 17, 2008, pp. 4254-4277. doi:10.1016/j.gca.2008.06.013

[9] J. S. Chen, F. Y. Wang and X. H. Xia, "Geochemistry of Rare Earth Elements in the Mainstream of the Yangtze River, China," Applied Geochemistry, Vol. 13, No. 4, 1998, pp. 451-462. doi:10.1016/S0883-2927(97)00079-6

[10] W. Z. Yue, Z. Q. Bi, S. D. Jiao and N. Y. Wei, "Study on Stratigraphic Sequence of the Mesozoic Continental Basin along the Lower Yangtze River in Jiangsu and Anhui Provinces," Geological Publishing House , Beijing, 2002, pp. 121-186.

[11] B. Dupré, J. Gaillardet, D. Rousseau and C. J. Allègre, "Major and Trace Element of River-Borne Material: The Congo Basin," Geochimica et Cosmochimica Acta, Vol. 60, No. 8, 1996, pp. 1301-1321. doi:10.1016/0016-7037(96)00043-9

[12] A. P. Davis, M. Shokouhian and S. Ni, "Loading Estimates of Lead, Copper, Cadmium, and Zinc in Urban Runoff from Specific Sources," Chemosphere, Vol. 44, No. 5, 2001, pp. 997-1009. doi:10.1016/S0045-6535(00)00561-0

[13] M. Meybeck and R. Helmer, "The Quality of Rivers: From Pristine Stage to Global Pollution," Palaeogeography, Palaeoclimatology, Palaeoecology, Vol. 75, No. 4, 1989, pp. 283-309. doi:10.1016/0031-0182(89)90191-0

[14] Y. L. Shi, Y. Wu and M. E. Ren, "Hydrological Characteristics of the Changjiang and Its Relation to Sediment Transport to the Sea," Continental Shelf Research, Vol. 4, No. 1-2, 1985, pp. 5-15. doi:10.1016/0278-4343(85)90018-4

[15] W. J. Cai, X. H. Guo, C. T. A. Chen, M. H. Dai, L. J. Zhang, W. D. Zhai, S. E. Lohrenze, K. D. Yin, P. J. Harrison and Y. C. Wang, "A Comparative Overview of 
Weathering Intensity and $\mathrm{HCO}_{3}^{-}$Flux in the World's Major Rivers with Emphasis on the Changjiang, Huanghe, Zhujiang (Pearl) and Mississippi Rivers," Continental Shelf Research, Vol. 28, No. 12, 2008, pp. 1538-1549. doi:10.1016/j.csr.2007.10.014

[16] R. Cidu and R. Biddau, "Transport of Trace Elements under Different Seasonal Conditions: Effects on the Quality of River Water in a Mediterranean Area," Applied Geochemistry, Vol. 22, No. 12, 2007, pp. 2777-2794. doi:10.1016/j.apgeochem.2007.06.017

[17] H. P. Jarvie, C. Neal, A. D. Tappin, J. D. Burton, L. Hill, M. Neal, M. Harrow, R. Hopkins, C. Watts and H. Wickham, "Riverine Inputs of Major Ions and Trace Elements to the Tidal Reaches of the River Tweed, UK," Science of the Total Environment, Vol. 251-252, 2000, pp. 55-81.

[18] K. S. Smith, "Metal Sorption on Mineral Surfaces: An Overview with Examples Relating to Mineral Deposits," Reviews in Economic Geology, Vol. 6A, 1999, pp. 161182.

[19] L. C. Zhang, Z. S. Yu and S. Zhang, "Researches on Chemical Elements of Aquatic Environment," China Environmental Science Press, Beijing, 1996, pp. 213-238.

[20] M. C. Gromaire, S. Garnaud, M. Saad and G. Chebbo, "Contribution of Different Sources to the Pollution of Wet Weather Flows in Combined Sewers," Water Research, Vol. 35, No. 2, 2001, pp. 521-533. doi:10.1016/S0043-1354(00)00261-X

[21] M. K. Koshikawa, T. Takamatsu, J. Takada, M. Y. Zhu, B. H. Xu, Z. Y. Chen, S. Murakami, K. Q. Xu and M. Watanabe, "Distributions of Dissolved and Particulate Elements in the Yangtze estuary in 1997-2002: Background Data before the Closure of the Three Gorges Dam," Estuarine, Coastal and Shelf Science, Vol. 71, No. 1-2, 2007, pp. 26-36. doi:10.1016/j.ecss.2006.08.010
[22] Z. F. Shi, X. Jiang, S. W. Yang, X. C. Jin and J. M. Cheng, "The Spatial and Temporal Variation Characteristics and Potential Ecological Risk Assessment of Heavy Metal Pollution in Surface Sediments of Chaohu, China," Journal of Ago-Environment Science, Vol. 29, No. 5, 2010, pp. 138-144.

[23] R. L. Bibby and J. G. Webster-Brown, "Characterisation of Urban Catchment Suspended Particulate Matter (Auckland Region, New Zealand): A Comparison with NonUrban SPM," Science of The Total Environment, Vol. 343, No. 1-3, 2005, pp. 177-197. doi:10.1016/j.scitotenv.2004.09.041

[24] B. Shi, H. E. Allen and M. T. Grassi, "Changes in Dissolved and Particulate Copper Following Mixing of POTW Effluents with Delaware River Water," Water Research, Vol. 32, No. 8, 1998, pp. 2413-2421. doi:10.1016/S0043-1354(97)00463-6

[25] A. Giorgi and L. Malacalza, "Effect of an Industrial Discharge on Water Quality and Periphyton Structure in a Pampeam Stream," Environmental Monitoring and Assessment, Vol. 75, No. 2, 2002, pp. 107-119. doi:10.1023/A:1014474128740

[26] B. Chetelat, C. Q. Liu , Z. Q. Zhao, Q. L. Wang, S. L. Li, J. Li and B. L. Wang, "Geochemistry of the Dissolved Load of the Changjiang Basin Rivers: Anthropogenic Impacts and Chemical Weathering," Geochimica et Cosmochimica Acta, Vol. 72, No. 17, 2008. pp. 4254-4277. doi:10.1016/j.gca.2008.06.013

[27] S. Roy, J. Gaillardet and C. J. Allegre, "Geochemistry of Dissolved and Suspended Loads of the Seine River, France: Anthropogenic Impact, Carbonate and Silicate Weathering," Geochimica et Cosmochimica Acta, Vol. 63, No. 9, 1999, pp. 1277-1292. doi:10.1016/S0016-7037(99)00099-X 